\title{
Requiem for Gary: Cultivating Wasteland in and beyond the "Age of Steel"
}

\author{
Angelo Van Gorp
}

\section{$1 \quad$ René Sand: Social Medicine}

In 1918, the Belgian government commissioned the Belgian social hygienist and pioneer of social medicine René Sand to conduct a study of Taylorism, or, as Sand himself defined it, "the science of organizing," which was occupied with mechanical efficiency and related physiological, psychological, and social factors. ${ }^{1}$ To this end, Sand visited factories, workshops, stores, insurance companies, public administrations, schools of various types and levels, museums, libraries, hospitals, social welfare institutions, and scientific, medical, labor, and employers' associations in both the United States and England. He also spoke to politicians, lawyers, judges, publishers, journalists, bankers, writers, and ordinary people. The key lesson Sand drew from his research was that even if an enterprise was well organized from a material point of view, its functioning would be precarious if the human factor was not taken into account. The quality, economy, and continuity of the production relied on the workers' health, assuring the ability to produce; general and vocational education, developing the talent to produce; and contentment, determining the willingness to produce. To Sand, it had become clear that industry was not simply about the art of fabricating. One had to adapt industry to men instead of the other way around. Efficiency does not go without beneficiency, he argued. ${ }^{2}$

1 René Sand, Organisation industrielle, médecine sociale et éducation civique en Angleterre et aux États-Unis (Brussels: Librairie Maurice Lamertin; Paris: Librairie J.-B. Baillière et fils, 1920), 5-17. On Sand's pioneering role in social medicine, see Michael Gard and Carolyn Pluim, Schools and Public Health: Past, Present, Future (Lanham, MD: Lexington Books, 2014), 19-23. In 1953, Sand was called "one of the most outstanding world leaders in public health"; see "René Sand [obituary]," American Journal of Public Health 43 (1953): 1476. Crucial to his international reputation was the volume Vers la médecine sociale (Paris: Baillière et fils, 1948), which was translated into English as Advance to Social Medicine, trans. Rita Bradshaw (New York: Staples Press, 1952).

2 Sand, Organisation industrielle, 26. Sand based his analysis on Ordway Tead, Instincts in Industry: A Study of Working-Class Psychology (Boston: Houghton Mifflin, 1918). 
What Sand proposed and advocated for was a social medicine that would play a pivotal role in urban-industrial society. Social medicine was conceived of as an umbrella science that, depending on where the emphasis was placed, either studied the medical factor in social problems or the social factors in medical questions. In that regard, social medicine was inextricably bound to the so-called social question and related processes of medicalization and educationalization. ${ }^{3}$ It was concerned with medical statistics and demography, referred to as the "photography of the nation" and the "cinematography of national life" respectively 4 ; social hygiene and pathology; health issues at the workplace; genetics and eugenics; as well as social, criminal, and educational anthropology, including experimental pedagogy, pedology, and pedotechnics. ${ }^{5}$ The latter is important for it not only demonstrates social medicine's ambition to replace pedology as the new holistic bio-psycho-social paradigm, it also reveals a continued interest in progressive education. ${ }^{6}$ In this respect, two references stand out in Sand's works: his acknowledgement of the work of his contemporary Ovide Decroly; and, related to his visit to the United States, his discussion of the public education system in Gary, Indiana.

\section{$2 \quad$ Ovide Decroly: Pedagogical Therapy}

As physicians, Sand and Decroly both looked at social problems and at the role education could play in dealing with them from a medical point of view. Although Ovide Decroly is first and foremost remembered for his pioneering

3 On the concept of medicalization, see, e.g., Robert A. Nye, "The Evolution of the Concept of Medicalization in the Late Twentieth Century," Journal of the History of the Behavioral Sciences 39, no. 2 (2003): 115-29. On the concept of educationalization, see, e.g., Marc Depaepe, Between Educationalization and Appropriation: Selected Writings on the History of Modern Educational Systems (Leuven: Leuven University Press, 2012); Paul Smeyers and Marc Depaepe, eds., Educational Research: The Educationalization of Social Problems (Dordrecht: Springer, 2009).

4 René Sand, L'économie humaine par la médecine sociale (Paris: Les Éditions Rieder, 1934), 19. Unless otherwise indicated, all translations are the author's.

5 Sand, Organisation industrielle, 718-20. His other works, too, reflect this approach; see particularly La santé de l'écolier (Brussels: Maison nationale d'édition l'Églantine, 1923); La Belgique sociale [Un inventaire et un plan d'action] (Brussels: J. Lebègue, 1933); L'économie humaine par la médecine sociale; un programme de la santé pour la Belgique (Brussels: Office de Publicité, 1945).

6 Angelo Van Gorp, "From Special to New Education: The Biological, Psychological, and Sociological Foundations of Ovide Decroly's Educational Work (1871-1932)," History of Education 34, no. 2 (2005): 135-49. 
role in new education, he was as much an adherent of the "cult of efficiency" as was Sand. ${ }^{7}$ For Decroly, just like for Sand, urban-industrial society served as a major frame of reference. And like Sand, Decroly, too, visited the United States, in his case to meet with well-known American professors, John Dewey being one of them, and to learn more about the scientific study of the child, especially about applied psychology. ${ }^{8}$ From that perspective, a parallel can be drawn between Sand's social-medical plea for a scientifically-based industry and Decroly's scientifically-based pedagogy, for in both approaches a desire to deeply understand the human factor went hand in hand with an attempt to increase efficiency. ${ }^{9}$ I would even go so far as to argue that the Decrolyan educational reform, which its adherents hailed as another Copernican revolution, was part of a rationalization of childhood aiming at social hygiene. Observation, recording, measurement, and quantification had become key features in Decroly's scientific study of the child (pedology) and its translation into educational practice (pedotechnics).

Modern urban-industrial society was a society plagued by social ills and diseases-alcoholism, syphilis, and tuberculosis foremost among them. ${ }^{10}$ In the alleys of the large cities, children would therefore run the risk of picking "the flowers of evil."11 This applied in particular to the many poor and working-class children whose plight served as a metaphor for the destructive and pathogenic city. Decroly called those children "the future recruits for the army of the degenerate who probably would end up in jail."12 Deviant behavior was a symptom of

$7 \quad$ Raymond E. Callahan, Education and the Cult of Efficiency: A Study of the Social Forces that Have Shaped the Administration of the Public Schools (Chicago: University of Chicago Press, 1970). Kliebard even refers to an "orgy of efficiency"; see Herbert M. Kliebard, The Struggle for the American Curriculum 1893-1958, 3rd ed. (New York: RoutledgeFalmer, 2004), 80.

8 On his study tour of the United States, Decroly was accompanied by Raymond Buyse, who recorded his impressions of the trip in a diary. See Marc Depaepe and Lieven D'hulst, eds., An Educational Pilgrimage to the United States: Travel Diary of Raymond Buyse, 1922 (Leuven: Leuven University Press, 2011).

$9 \quad$ Sand, Organisation industrielle, $15^{8}$.

$10 \quad$ Ovide Decroly, "Plaies sociales et remèdes," Revue Contemporaine: Pour l'École 1 (1904): 406-10.

11 Ovide Decroly, "Discours d'ouverture: Ve Congrès belge de Neurologie et de Psychiatrie (Mons 25-26 septembre 1909)," Journal de Neurologie 14, no. 21 (1909): 412; see also Ovide Decroly and Raymond Buyse, Les applications américaines de la psychologie à l'organisation humaine et à l'éducation (Brussels: Lamertin, 1923).

12 Ovide Decroly et al., "Questionnaire pour servir à la confection du dossier médicopédagogique," La Policlinique 15, no. 15 (1906): 226; see also Ovide Decroly, "Prophylaxie et traitement de l'enfance anormale: Le rôle du médecin," L'École Nationale 9, no. 2 (1909): 4-5. 
a sick society, and prisons "gnaw[ed] away at society like a cancer."13 It was absolutely necessary for society to be cured, otherwise it would be "stricken with gangrene."14 Education could absorb the potentially pernicious influences of the home environment and the alleys and assure the future of the human species. The existing schools therefore had to be transformed into schools that really prepared children for life, read: modern, urban-industrial society. The ultimate goal was a society freed from social ills and an ideal, peaceful, and prosperous life - in short, the new era many educational reformers longed for.

What was needed, Decroly argued, was a "pedagogical therapy."15 Mental tests were applied in order to check the mental capacity of each child. These mental tests were to enable the homogenization of groups and the individualization of instruction. The real aim of these tests was to improve the pedagogical methods applied. A differential psychology had to correspond with an "individual pedagogy."16 This necessitated, however, a radical shift from a collective to an individualized way of instruction that would be in accordance with the mental capacity of each individual child. The Decroly Method not only was essentially based on the child's main interests; it also ascribed an important role to educative games in the child's learning process. Many of those games were derived from mental tests and became the quintessence of the intensification, or Taylorization, of the three Rs with a view to improving their efficiency. ${ }^{17}$ The ultimate goal was "to Taylorize instruction in order to valorize education."18

Conceived of as a "pedagogy of efficiency" aiming at the socialization of as many children as possible, the Decroly Method used mental tests in order to determine norms for each category of pupils, such as the normal, the "pedagogically and medically backward," and the more gifted child. ${ }^{19}$ In this respect, the benchmark was not the normal, that is, the average (compare Quetelet's notion of "the average man"), but the level of perfectibility of each different category. ${ }^{20}$ It therefore could be argued that Decroly's scientific work to a very large

\footnotetext{
13 [Ovide Decroly], Dr. Ovide Decroly, 1871-1932. Toespraak gehouden te Ronse in 1904: Tekst van de onuitgegeven redevoering (Ghent: Departement Onderwijs, [1904]), 23.

14 Ibid., 24.

15 Decroly and Buyse, Les applications américaines, 52.

16 Ibid., 41.

17 See Anson Rabinbach, The Human Motor: Energy, Fatigue, and the Origins of Modernity (Berkeley: University of California Press, 1992).

18 Decroly and Buyse, Les applications américaines, 56.

19 Ibid., $5^{2}$.

20 See André Turmel, "Towards a Historical Sociology of Developmental Thinking: The Case of Generation," Paedagogica Historica 40, no. 4 (2004): 419-33.
} 
extent corresponded with Sand's social-medical agenda. ${ }^{21}$ Medicine, according to Sand, not only had to be curative and preventive, but also constructive and perfective. ${ }^{22}$ Like the engineers who had made machines and procedures more effective in industry, hygienists would take care of the "human machine" in society. Modern urban-industrial society had entered the "era of psychology." 23

\section{Gary, Indiana: An Educational Wasteland}

Had the Decroly Method materialized into a corresponding school building in the United States, it might have looked like the huge model schools in Gary, Indiana, based on John Dewey's ideas: the Emerson and Froebel schools. Like the Decroly School in Brussels, they attracted visitors from all over the world who wanted to catch "a glimpse of the future."24 Given the striking similarities, it is very likely that Decroly's pencil sketch of the ideal school is based on Graham Romeyn Taylor's map showing the layout of Gary's Froebel school as it was reproduced in Sand's 1920 volume..$^{25}$ The school buildings were designed by William B. Ittner (1864-1936), who has been called "the most influential man

21 It equally could be argued that branding the Decroly Method as merely "bourgeois" is ignoring the subject in the "Decroly delta" or, to put it differently, the varied classes, ranks, types, and categories the converging and diverging constructions in Decroly's scientific works touched upon. It did not prevent Decroly, and particularly the Decrolyans, from being convinced that the Decroly School as a true avant-garde school had to target an elite whose role and importance was to guide the masses and to bring happiness to an urbanindustrial society that itself created backwardness and abnormality. See Van Gorp, "From Special to New Education"; Angelo Van Gorp, Marc Depaepe, and Frank Simon, "Backing the Actor as Agent in Discipline Formation: An Example of the 'Secondary Disciplinarization' of the Educational Sciences, Based on the Networks of Ovide Decroly (1901-1931)," Paedagogica Historica 40, nos. 5-6 (2004), 591-616.

22 Sand, L'économie humaine, 244.

23 Ibid., 191.

24 William J. Reese, foreword to Children of the Mill: Schooling and Society in Gary, Indiana, 1906-196o, by Ronald D. Cohen (Bloomington: Indiana University Press, 1990), x.

25 Graham Romeyn Taylor, Satellite Cities: A Study of Industrial Suburbs (New York: Appleton, 1915), 222; Sand, Organisation industrielle, 755-56; Decroly's pencil sketch is reproduced in Frederik Herman et al., "Modern Architecture Meets New Education: Renaat Braem's Design and the Brussels Decroly School (1946)," Belgisch Tijdschrift voor Nieuwste Geschiedenis/Revue Belge d'Histoire Contemporaine 41, nos. 1-2 (2011): 135-66; see also Frederik Herman et al., "Auf den Spuren von Diskurs, Traum und Wirklichkeit der architektonischen Formgebung in Decrolys Ermitage," Zeitschrift für Pädagogik 57 (2011): 928-51. 
in school architecture in the United States."26 The E-shaped schools became Ittner's trademark and were perceived as the ideal school plants, "creations of unusual beauty and impressiveness."27 The layout reflected Dewey's ideas of what a school had to look like in order to avoid waste and to secure an organic connection with social life. ${ }^{28}$ The plant, in its physical aspect, was more than a mere collection of facilities, since the facilities "fit into one another according to a very comprehensive plan" and formed "organs of a genuine school life," reflecting a belief in educating "the whole child," physically, artistically, scientifically, manually, as well as intellectually. ${ }^{29}$

Gary's superintendent of schools, William Wirt, had the "advantage of having a virgin field in which to work." ${ }^{30}$ One might also call it an educational wasteland. Essentially, the Gary Plan represented an effort to apply to an urban school system Dewey's idea of education as an "embryonic community life." 11 Emphasis was on the school as "a social clearinghouse for the neighborhood." ${ }^{2}$ In Dewey's words: "Using the school plant as a social center is recognition of the need for social change and of the community's responsibility to help effect it." ${ }^{33}$ The most distinctive feature of the Gary Plan was the so-called "workstudy-play plan" or "platoon system," a way of doubling the capacity of the schools by taking advantage of the fact that when one group of pupils was using the auditoriums, shops, laboratories, and playgrounds, another group could make use of the classrooms. ${ }^{34}$

26 Virginia E. McCormick, Architecture in Ohio: From One-Room Schools and Carnegie Libraries to Community Education Villages (Kent, OH: Kent State University Press, 2001).

27 Randolph S. Bourne, The Gary Schools (1916; Cambridge, MA: MIT Press, 1970), 23.

28 John Dewey, The School and Society: Being Three Lectures (Chicago: University of Chicago Press, 1899), 77-78, 89, 93-94; see also John Dewey, Democracy and Education: An Introduction to the Philosophy of Education (New York: Macmillan, 1916), 416.

29 Bourne, The Gary Schools, 14, 32.

30 Ibid., 10.

31 Lawrence A. Cremin, The Transformation of the School: Progressivism in American Education 1876-1957 (New York: Vintage Books, 1961), 155. On the relation between Dewey and Wirt, see Malcolm Thorburn, "John Dewey, William Wirt and the Gary Schools Plan: A Centennial Reappraisal," Journal of Educational Administration and History 49, no. 2 (2017): 144-56. Thorburn argues that "[w]hile much has been made of Wirt being a 'disciple of Dewey' ... the extent to which this is the case is not noticeably discernible from a review of the correspondence between the two men." He adds: "In fact, there is no evidence that the two men ever met in person (although it is possible that Wirt was tutored by Dewey when in class at the University of Chicago)"; ibid., 149 .

32 John Dewey and Evelyn Dewey, Schools of Tomorrow (1915; New York: E. P. Dutton, 1962), 197.

33 Ibid., 227.

34 Arthur Zilversmit, Changing Schools: Progressive Education Theory and Practice, 1930-196o (Chicago: University of Chicago Press, 1993); see also the notion of "activity centers" as 
As Sand's work underlines, the public education system in Gary, Indiana, is one of the most telling examples of progressive education in the United States. ${ }^{35}$ It has been discussed extensively in American scholarship on educational history. ${ }^{36}$ The Gary Plan is also the most comprehensive example of schools working with "a curriculum that is truly representative of the needs and conditions of a democratic society," as discussed by Dewey and his daughter Evelyn in Schools of Tomorrow, published in 1915. ${ }^{37}$

As Gary's history is inextricably bound up with both the heyday and the decline of the steel industry in the United States, the case of Gary can be seen as emblematic of the "age of steel." Indeed, soon after the U.S. Steel Company was established in 1901, the company became a billion-dollar industrial empire and urgently needed more capacity to maintain its share of the booming steel market. In 1906, it started acquiring land in Lake County, Indiana, along the southern shore of Lake Michigan almost thirty miles southeast of Chicago. A new steel town arose that was named for Elbert Henry Gary (1846-1927), the first chairman of the board of U.S. Steel. Gary became a symbol of urbanindustrial America in the Progressive Era, and it is considered the largest attempt at urban genesis and town planning ever undertaken by American industry. ${ }^{38}$ It was hailed as "a huge technical miracle" and the "New Industrial Utopia."39 Gary's steelmaking facilities were to be not only the world's largest at the time, covering an area of a square mile, but also the most modern, using the latest methods and technology. ${ }^{40}$ Because of its mushroom growth, Gary was called "America's Magic City of Steel."11 In Dewey's words, "the town was made ... at a stroke and ha[d] grown rapidly from a waste of sand dunes to a prosperous

explained by Karin Priem and Frederik Herman in "Sensuous Geographies' in the 'Age of Steel': Educating Future Workers' Bodies in Time and Space (1900-1940)" (in this volume). Bourne also referred to this departmentalization as the "rotation-of-crops" system, see Bourne, The Gary Schools, 64.

36 See, e.g., Kliebard, The Struggle for the American Curriculum; Susan F. Semel and Alan R. Sadovnik, eds., "Schools of Tomorrow, Schools of Today": What Happened to Progressive Education (New York: Peter Lang, 1999); Zilversmit, Changing Schools; Cohen, Children of the Mill; Cremin, The Transformation of the School.

37 Dewey and Dewey, Schools of Tomorrow, 288.

38 Anthony Brook, "Gary, Indiana: Steeltown Extraordinary," Journal of American Studies 9, no. 1 (1975): 35 .

39 Adeline Levine and Murray Levine, "Introduction to the New Edition: The Gary Schools, a Sociohistorical Study of the Process of Change," in Bourne, The Gary Schools, xxvii; S. Paul O'Hara, Gary: The Most American of All American Cities (Bloomington: Indiana University Press, 2011).

40 Brook, "Gary, Indiana."

41 O'Hara, Gary. 
town." ${ }^{42}$ While the sensuous geography of an industrial town has (inevitably?) been linked to the drabness of industrialism, ${ }^{43}$ Gary quickly became home to thousands of "millhands" who had their own myriad ways of inhabiting, experiencing, and sensing the town. ${ }^{44}$

Soon after it was founded, Gary became a town of mostly Eastern and Southern European working-class immigrants. ${ }^{45}$ It instantly developed a vibrant community life offering public transport, sports facilities, city parks, playgrounds, public libraries, saloons, theaters, churches, settlement houses, beaches, and much more. The explosive growth to 55,000 inhabitants by 1920 and 100,000 by 1930 nevertheless brought a host of social problems. In its early years, Gary combined the tough atmosphere of a "frontier boomtown" with the virtues and vices of the "instant city," as well as the "typical municipal evils of graft, franchise fights, saloon dominance, insufficient housing and health regulation, election frauds, and lack of social cohesion." ${ }^{26}$ Offering the rare opportunity of planning a new city from scratch, backed by the financial and organizational resources of the huge industrial empire of U.S. Steel, Gary obviously represented an urban planner's dream. Alas, the dream quickly turned into a nightmare. ${ }^{47}$ Its dramatic growth did not prevent Gary from becoming a typical American city, or, like the historian Paul O'Hara phrased it, even "the most American of all American cities." 48

In order to avoid the urban tragedy of the model city of Pullman, Illinois, built in the 1880s, U.S. Steel, unlike the Pullman Company, did not aim to create a social utopia. ${ }^{49}$ In fact, different from Pullman, where the company owned all housing and exercised paternalistic control over the morals and behavior of the workers and their families, U.S. Steel conceived of Gary as a mere center of production "guided by geography, not philanthropy" 50 The physical structure created, as it were, three Garys: a mill town in the north alongside

42 Dewey and Dewey, Schools of Tomorrow, 268; see also Bourne, The Gary Schools, 3-4; Cremin, The Transformation of the School, 154.

43 Andrew Hurley, "Challenging Corporate Polluters: Race, Class and Environmental Politics in Gary, Indiana, since 1945," Indiana Magazine of History 88 (1992): 273-302.

44 Warner Bloomberg, Jr., and Victor F. Hoffmann, Jr., "The Recession Hits Gary, Indiana: Smiling Through?," Commentary 26, no. 1 (1958): 16.

45 Neil Betten and Raymond A. Mohl, "The Evolution of Racism in an Industrial City, 19061940: A Case Study of Gary, Indiana," The Journal of Negro History 59, no. 1 (1974): 51-64.

46 Brook, "Gary, Indiana"; Zilversmit, Changing Schools, 57; Bourne, The Gary Schools, 3.

47 Brook, "Gary, Indiana," 43.

48 O'Hara, Gary: The Most American of All American Cities.

49 Ibid.; see also Stanley Buder, Pullman: An Experiment in Industrial Order and Community Planning, 1880-1930 (New York: Oxford University Press, 1967).

5o O'Hara, Gary: The Most American of All American Cities, 44. 
the lake; a model town in the center encompassing the business district called "the First Subdivision"; and an industrial periphery in the south called "the Patch." The first and the second were divided from each other by the Grand Calumet River, the second and the third by the Wabash railroad tracks. As a consequence, the social division within Gary was a geographical reality from the outset. While the First Subdivision was planned with generally good housing and sanitation and catered for business and professional people and skilled workers, the South Side developed rapidly and disorderly into an insanitary and overcrowded slum area with poor-quality housing for the unskilled immigrant workers. The concept of the model industrial city of Gary was "destroyed before it got off the ground."51

It was in this context that Wirt decided to counter what he called the "education that the child gets on the streets and alleys" - thus taking an approach that forms a striking parallel with Sand's and Decroly's social-hygienist agenda. ${ }^{52}$ By removing the opportunity for wasted "street and alley time" and by placing the working-class immigrant child under "the helpful, constructive influence of the school throughout the day," Wirt hoped to develop "a full rounded character, as well as an efficient school product."53 According to Dewey, "[h] ealth is as important from the social point of view as from the individual, so that attention to it is doubly necessary to a successful community." ${ }^{\prime 5}$ What was needed, then, was "a reorganization of the ordinary schoolwork to meet the needs of this class of pupils [working-class children], so that they will wish to stay in school [instead of hanging around on the streets and alleys] for the value of what they are learning." The ideal was not "to use the schools as tools

$51 \quad$ Brook, "Gary, Indiana," 46.

52 William Albert Wirt, Newer Ideals in Education: The Complete Use of the School Plant. An Address Delivered Before the Public Education Association in the New Century Drawing Room, January 30, 1912 (Philadelphia: Public Education Association, 1912), 4. Although Wirt had studied educational methods in Belgium, England, France, and Germany—see Dictionary of American Biography (1940), s.v. "Wirt, William Albert" — and Dewey influenced both Decroly and Wirt, there most probably is no direct link between them. With reference to the social question, social-hygienic interventions were inherent to modern urban-industrial society. On the influence of Dewey on Decroly, see Angelo Van Gorp, "Ovide Decroly: Warum sollten wir ihn erforschen?," Zeitschrift für pädagogische Historiographie 13, no. 1 (2007): 6-13; Angelo Van Gorp, Tussen mythe en wetenschap: Ovide Decroly (1871-1932) (Leuven: Acco, 2005), 237-48; Tom De Coster et al., "Dewey in Belgium: A Libation for Modernity? Coping with His Presence and Possible Influence," in Inventing the Modern Self and John Dewey: Modernities and the Travelling of Pragmatism in Education, ed. Tom Popkewitz (New York: Palgrave Macmillan, 2005), 85-109.

53 Wirt, Newer Ideals in Education, 14; see also Bourne, The Gary Schools, 38.

54 Dewey and Dewey, Schools of Tomorrow, 290. 
of existing industrial systems" but "to use industry for the reorganization of the schools." 55

In Gary, the pupils had the opportunity to learn the specific skills for different professions: "[F]rom the first day he [the pupil] went to school he has been doing work that teaches the motives and principles of the uses to which the material world is put by his social environment, so that whatever work he goes into will really be a vocation, a calling in life, and not a mere routine engaged in only for the sake of pay." 56 It is the kind of "vocational" education Dewey distinguished from "trade" education, which he considered "an instrument of perpetuating unchanged the existing industrial order of society." 57 The place of industry in education was "not to hurry the preparation of the individual pupil for his individual trade." ${ }^{58}$ Learning was not the work of "something readymade called mind." According to Dewey, mind itself was an "organization of original capacities into activities having significance." ${ }^{59}$ Vocational training, then, became a means of transforming the existing industrial order of society. The democracy which proclaimed "equality of opportunity" as its ideal required an education in which learning and social application, ideas and practice, work and recognition of the meaning of what is done are united from the beginning and for all. ${ }^{60}$ Dewey praised the Gary schools, for they were "showing how the ideal of equal opportunity for all is to be transmuted into reality" 61

Because of the publicity and support by scholars and opinion-makers like Dewey, the platoon system spread rapidly. In 1961, the American historian of education Lawrence Cremin wrote that "by 1916 it seems fair to say that most progressives, if asked to cite the leading example of progressive education, would probably have mentioned Gary" 62 Indeed, in the 1920 s the plan was being used in over 1,000 schools in approximately 200 cities in 41 states in the United States, with an estimated enrolment of over 730,0oo students around

\footnotetext{
55 Ibid., 311.

56 Ibid., 265 .

57 Dewey, Democracy and Education, 369.

$5^{8}$ Dewey and Dewey, Schools of Tomorrow, 312.

59 Dewey, Democracy and Education, 368.

60 Dewey and Dewey, Schools of Tomorrow, 315 .

61 Ibid., 316.

62 Cremin, The Transformation of the School, 155.
} 
1920. ${ }^{63}$ According to Thomas D. Fallace, another historian of education, the platoon system represented "the quintessence of progressive education" because of its use of administrative efficiency, its hands-on learning, its fusing of an academic and an industrial curriculum, its focus on the whole child, and its engagement with the community. ${ }^{64}$ Although the Deweys were most impressed with the "social and community idea," it was the efficiency of the ways in which the school plant was used that contributed the most to the success and extensive growth of the platoon system. ${ }^{65}$ Efficiency was "the heart and soul" of the platoon system, as Cohen phrased it, and no city embraced the "gospel of efficiency" as ardently as Gary. ${ }^{66}$ As an educational innovation, the Gary Plan was clearly more managerial than curricular: the plan provided an enriched educational program for children, but more important was the administrative argument of financial savings. ${ }^{67}$ It was with good reason that the educationist John Franklin Bobbitt (1876-1956) referred to Wirt as an "educational engineer." The term "plant" had implications far broader than "the pedestrian question of space utilization." 68

The appropriation of the Gary Plan - that is, the "platooning" or "Garyizing" of systems throughout the United States ${ }^{69}$ — nevertheless resulted mostly in a kind of semi-departmentalization. ${ }^{70}$ It was criticized as a "part-time" scheme that accentuated "the usual evils of fragmentary schooling and demoralizing street life." ${ }^{71}$ As a result, the platoon system would soon disappear from the national scene. ${ }^{72}$ The Gary Plan itself began to unravel in the 1930 s and was soon dismantled after Wirt's death in 1938. A survey of the Gary schools in 1940 described a public education system that had become "stultified in routine";

63 Callahan, Education and the Cult of Efficiency, 413.

64 Thomas D. Fallace, Race and the Origins of Progressive Education, 1880-1929 (New York: Teachers College Press, 2015), 136.

65 Callahan, Education and the Cult of Efficiency, 57.

66 Ibid., 126; Cohen, Children of the Mill, 121; see also Reese, foreword to Children of the Mill, x; Kliebard, The Struggle for the American Curriculum, 76 .

67 Kliebard, The Struggle for the American Curriculum, 83; Cremin, The Transformation of the School.

68 John Franklin Bobbitt, "The Elimination of Waste in Education," The Elementary School Teacher 12, no. 6 (1912): 260-61, cited in Kliebard, The Struggle for the American Curriculum, 83 .

69 David Levine, "The Milwaukee Platoon School Battle: Lessons for Activist Teachers," The Urban Review 34, no. 1 (2002): 47-69.

70 Don C. Bliss, "Platoon Schools in Practice," The Elementary School Journal 20, no. 7 (1920): 510-15.

71 Bourne, The Gary Schools, 64.

72 Larry Cuban, "How Schools Change Reforms: Redefining Reform, Success and Failure," Teachers College Record 99, no. 3 (1998): 453 . 
the report noted "an almost religious devotion to the past" and a "creeping dilapidation" of many aspects of a system that but a few years earlier was "among the most glorious of educational triumphs."73 It lasted in some form or another until 1960 when the system finally died "after a protracted illness." ${ }^{74}$ Ironically, the school plants once hailed as ideal were either closed or demolished around the time of Gary's centennial.

\section{5}

Gary, Indiana: Stretching beyond the Age of Steel

The historian William J. Reese once wrote that "the historian's job is to ensure that we remember what too many people forget." He made this statement in 1990, when many citizens, he wrote, may think of Gary as only "one of America's numerous northern, rust belt cities, its schools impaired by familiar urban ills resulting from the legacy of racial discrimination and poverty amidst a collapsing economy"75 Indeed, like other once-thriving centers of manufacturing, Gary ultimately became a ghost town. Today, Gary is a city plagued by physical decay, joblessness, concentrated poverty, and racial isolation. ${ }^{76}$ Houses are crumbling, and lots lie empty on Broadway and Fifth Avenue, whose intersection was once the center of the business district. ${ }^{77}$ Whole rows of shops and stores are boarded up and graffiti-covered. A blaze that swept through downtown Gary in October 1997 destroyed landmark buildings like the Memorial Auditorium and the Methodist Church. Gary made a journey from urban heyday to decay, from utopia to dystopia, from natural to urban wasteland. As a post-industrial city, it returned to its pre-industrial state with a touch of rust.

73 Callahan, Education and the Cult of Efficiency, 58.

74 Cohen, Children of the Mill, xiv, xvii, 158; Cuban, "How Schools Change Reforms," 453.

75 Reese, foreword to Children of the Mill, $\mathrm{x}$. The Rust Belt is the heavy-manufacturing region bordering the Great Lakes. The steel industry, car companies, and rubber tire production were the biggest Rust Belt industries. In the 1950s, the Rust Belt was an economic giant, accounting for more than half of all U.S. manufacturing jobs and about 43 percent of all U.S. jobs. See Simeon Alder, David Lagakos, and Lee Ohanian, Competitive Pressure and the Decline of the Rust Belt: A Macroeconomic Analysis, NBER Working Paper No. 20538 (Cambridge, MA: National Bureau of Economic Research, October 2014); Lee E. Ohanian, Competition and the Decline of the Rust Belt, Economic Policy Paper 14-6 (Federal Reserve Bank of Minneapolis, December 2014); see also George Hobor, "Surviving the Era of Deindustrialization: The New Economic Geography of the Urban Rust Belt," Journal of Urban Affairs 35, no. 4 (2012): 417-34.

76 Thomas J. Sugrue, The Origins of the Urban Crisis: Race and Inequality in Postwar Detroit (Princeton, NJ: Princeton University Press, 2005).

Brook, "Gary, Indiana," 43. 
The white population, still comprising 80 percent of the population in 1930, dropped to 60 percent by 1960 and to 10 percent by 2000 . Simultaneously, Gary's African-American population grew exponentially from less than 20 percent during the 1930 s to almost 40 percent in 1960 and over 80 percent in 1990. The population, which peaked at approximately 178,000 in 1960 , has decreased to approximately 76,000 today. ${ }^{78}$ This demographic decline cannot be explained by economic factors only. As Sugrue argues, "[i]t is only through the complex and interwoven histories of race, residence [space], and work [economy] in the postwar era that the state of today's cities and their impoverished residents can be fully understood and confronted." $79 \mathrm{~A}$ decisive factor in this process was the election in 1967 of Richard Gordon Hatcher, the city's first black mayor. Fear of a city run by a black mayor led many white residents to leave Gary. It was the moment that Gary became a black city. ${ }^{80}$ The white flight also meant that most schools in Gary became entirely black.

Like in other cities in the Northeast, Midwest, and West, the race question in Gary mainly goes back to the Great Migration, also called a "migration of desperation," which roughly took place between 1910 and $1970 .{ }^{81}$ During this massive internal migration, African Americans left the rural South and met with poverty and racism from northern whites and immigrants who quickly learned the "color status hierarchy." ${ }^{2}$ In Gary, the African Americans were forced into the Patch, where they settled among the immigrant groups. African Americans

${ }_{78}$ United States Census Bureau, "Quick Facts—Gary, Indiana," https://www.census.gov / quickfacts/fact/table/garycityindiana/PST045216; Stats Indiana, "Indiana City/Town Census Counts, 1900-2010," http://www.stats.indiana.edu/population/PopTotals/historic_counts_cities.asp.

79 Sugrue, The Origins of the Urban Crisis, 5 .

8o O'Hara, Gary, 138, 146; see also James H. Lytle, "Urban School Reform: To What End?," in International Handbook of Urban Education, ed. William T. Pink and George W. Noblit (Dordrecht: Springer, 2007), 861.

81 Mordecai W. Johnson, "The Negro and His Relationships," National Conference on Social Welfare Proceedings (1937): 64 .

82 Theresa Richardson, "Moral Imperatives for the Millennium: The Historical Construction of Race and Its Implications for Childhood and Schooling in the Twentieth Century," Studies in Philosophy and Education 19 (2000): 301-27; Sugrue, The Origins of the Urban Crisis; Zeus Leonardo and Margaret Hunter, "Imagining the Urban: The Politics of Race, Class, and Schooling," in Pink and Noblit, International Handbook of Urban Education, 781; Betten and Mohl, "The Evolution of Racism in an Industrial City," 64. As De Genova argues, the defining and decisive feature of U.S. racist hegemony "has always been, and continues to be, precisely the systematic maintenance of a racial hierarchy in which whiteness is exclusively guarded as the most privileged condition [i.e., white supremacy]." See Nicholas De Genova, "The Stakes of an Anthropology of the United States," The New Centennial Review 7, no. 2 (2007): 250. 
soon replaced the foreign-born laborers, which led to the ghettoization of the Patch. ${ }^{83}$ By World War II, Gary had a clearly defined black ghetto, which was also enforced by the physical layout of the city as described above. ${ }^{84}$ In this heavily segregated Gary, race would be a "continual sticking point." 85

As a result of its emphasis on local conditions, with "environment" and "neighborhood" being the central notions, Dewey's discussion, in Schools of Tomorrow, of the Gary schools glided over this race question. In fact, Dewey accepted the status quo and what has been described as "de-facto segregation" in a multiracial, multiethnic, class-structured urban setting. ${ }^{86}$ In addition, one should bear in mind that the great influx of African Americans to Gary only started with the 1919 steel strike, when they were used as strikebreakers. ${ }^{87}$ That was five years after Evelyn Dewey had visited Gary. Visual documents, too, show only a few African Americans and a strongly segregated Gary. The photobook Steel Giants, for example, shows images from the image collection created by U.S. Steel and Inland Steel, housed in the Calumet Regional Archives. ${ }^{88}$ The book primarily documents the first fifty years, until circa 1950, so it only shows

83 Brook, "Gary, Indiana," 49; Betten and Mohl, "The Evolution of Racism in an Industrial City," 5 2.

84 Betten and Mohl, "The Evolution of Racism in an Industrial City," 64.

85 Cohen, Children of the Mill, 156.

86 William W. Brickman, introduction to Dewey and Dewey, Schools of Tomorrow, xxiv-xxv; see, e.g., John Dewey, "The School as a Means of Developing a Social Consciousness and Social Ideals in Children," National Conference on Social Welfare Proceedings (1923): 450; see also Semel and Sadovnik, "Schools of Tomorrow, Schools of Today," 364-65; Cohen, Children of the Mill. After the Supreme Court case of Brown v. Board of Education in 1954, for instance, the Gary School Board argued that "it was not responsible for integrating unintentional segregation caused by racial separation in neighborhoods" by calling the phenomenon "de-facto segregation"; cited in O'Hara, Gary, 137. One of the more critical pieces on Dewey as (essentially) racist is Frank Margonis, "John Dewey's Racialized Visions of the Student and Classroom Community," Educational Theory 59 (2009): 17-39. On Dewey's supposed silence on race, see also, e.g., Fallace, Race and the Origins of Progressive Education; Thomas D. Fallace, "Recapitulation Theory and the New Education: Race, Culture, Imperialism, and Pedagogy, 1894-1916," Curriculum Inquiry 42, no. 4 (2012): 510-33; Thomas D. Fallace, "Was John Dewey Ethnocentric? Reevaluating the Philosopher's Early Views on Culture and Race," Educational Researcher 39, no. 6 (2010): 471-77; Thomas D. Fallace, "Repeating the Race Experience: John Dewey and the History Curriculum at the University of Chicago Laboratory School," Curriculum Inquiry 39, no. 3 (2009): 381-405. On "white philosophy," see also Michael A. Peters, "Why Is My Curriculum White?," Educational Philosophy and Theory 47, no. 7 (2015): 641-46.

87 Brook, "Gary, Indiana," 41; Betten and Mohl, "The Evolution of Racism in an Industrial City," 52.

88 Stephen G. McShane and Gary S. Wilk, Steel Giants (Bloomington, IN: Quarry Books, 2009). The different sections show the building of the steel mills, the production of steel, the steel communities, and the steel people. 
the heyday of the steel industry. The photographs contrast strongly with Gary's ruin photography — some refer to it as "ruin pornography"89 — which aestheticizes and dramatizes spaces without any attempt to inquire what it meant to the people who inhabited them.

As Greg Grandin has argued with respect to Detroit, "degeneration was always already built into the opulence." 90 With Ann Laura Stoler, I would like to suggest that we look at Gary's ruins, including the abandoned schools and auditoriums, as "imperial debris" - that is, as "imperial formations" defined by racialized relations of allocations and appropriations..$^{91}$ These ruins are not just memorialized and large-scale monumental "leftovers" or relics of a glorious past, but "the aftershocks of empire ..., the material and social afterlife of structures, sensibilities, and things" that "reside for instance in the gutted infrastructure of segregated cityscapes." ${ }^{\prime 2}$ Colonialism is not a closed story, since racism replaced slavery as a "tool of social control in the concentration and segregation of African Americans at the bottom of society" ${ }^{\prime 3}$ The notion of "empire" here is referring both to the "imperial configuration of the United States," emphasizing the "colonial dimensions of U.S. nationalism and national identity," and to Gary's particular history in which racialized segregation is inextricably bound to the role the industrial empire of U.S. Steel played in the development of Gary. ${ }^{94}$

Arthur Naparstek, an expert on urban redevelopment and neighborhood revitalization, calls it "one of our fundamental mistakes ... that policies have not focused on people" and defines "the small community neighborhood as the locus for service delivery." ${ }^{95}$ His plea for partnership in order "to make

89 Dora Apel, Beautiful Terrible Ruins: Detroit and the Anxiety of Decline (New Brunswick, NJ: Rutgers University Press, 2015). For examples of Gary's ruin photography, see, for instance: http://www.forbidden-places.net/urban-exploration-gary-indiana-ghost-town\# 1 https://nl.pinterest.com/pittmoss/indiana-dunes-ruins-of-gary/

http://www.darkroastedblend.com/2011/o7/exploring-ruins-of-gary-indiana.html http://www.dewitzphotography.com/personal-photography-projects/ruin-porn -of-the-past-united-states-murder-capital-gary-in/

http://desertedplaces.blogspot.com/2016/o4/the-abandoned-ruins-of-gary-indiana. html.

9o Greg Grandin, "Empire's Ruins: Detroit to the Amazon," in Imperial Debris: On Ruins and Ruination, ed. Anna Laura Stoler (Durham, NC: Duke University Press, 2013), 116.

91 Ann Laura Stoler, "Imperial Debris: Reflections on Ruins and Ruination," Cultural Anthropology 23, no. 2 (2008): 193 .

92 Ibid., 194.

93 Ibid., 210; Richardson, "Moral Imperatives for the Millennium," 317.

94 De Genova, "The Stakes of an Anthropology of the United States," 243, 247.

95 Arthur J. Naparstek, "Community Empowerment: The Critical Role of Neighborhoods," National Conference on Social Welfare Proceedings (1980): 56 . 
democracy real" is based on his experience in the late 196os, when he worked in Gary as an assistant to mayor Hatcher. What is needed to make that partnership happen is "the dependence of social reorganization upon educational reconstruction," as Dewey phrased it in Democracy and Education: "It signifies a society in which every person shall be occupied in something which makes the lives of others better worth living, and which accordingly makes the ties which bind persons together more perceptible - which breaks down the barriers of distance between them." ${ }^{\text {"6 }}$ Dewey warned, however, "that we are far from such a social state" and added that, "in a literal and qualitative sense, we may never arrive at it." 97

In 1923, in the aftermath of the First World War, Dewey referred to "the growth in the last ten years of social intolerance" as " $t \mathrm{t}]$ he most discouraging symptom of American life today," arguing that "these causes of division, of separation, and of mutual distrust may not go on growing among us," and emphasizing the importance of social work by urging teachers to be "leaders in social work." 98 More recently, Ian Shaw referred to "the urban desert" when pointing at the unexplored potential for social work research and practice in the city. ${ }^{99}$ Indeed, there is more wasteland to be cultivated by both researchers and practitioners in order to make the city an "arena for learning democracy."100 Looking at Gary, then, their focus should be on an economic turnaround for the Rust Belt, an urban economic transformation, or an emphasis on "postdeindustrialization" rather than on "deindustrialization."101 In this process, renewed interest should go to the school as a social clearinghouse by (re)establishing bonds between schools and neighborhoods that, in conjunction with forms of non-formal education and community work, hold the potential

96 Dewey, Democracy and Education, 369, 373 .

97 Ibid., 370.

98 Dewey, "The School as a Means of Developing a Social Consciousness," 450, 453.

99 Ian Shaw, "Social Work Research: An Urban Desert?," European Journal of Social Work 14, no. 1 (2011), 11-26. Seen from this perspective, it is no coincidence that Sand is first and foremost remembered as a pioneer of international social work. See, e.g., Kerstin Eilers, "René Sand (1877-1953) and His Contribution to International Social Work, IAssw-President 1946-1953," Social Work \& Society 5, no. 1 (2007): 102-9; Lynne M. Healy, "Introduction: A Brief Journey Through the 80 Year History of the International Association of Schools of Social Work," Social Work \& Society 6, no. 1 (2008): 115-27; Anette Kniephoff-Knebel and Friedrich W. Seibel, "Establishing International Cooperation in Social Work Education: The First Decade of the International Committee of Schools for Social Work (ICSSW)," International Social Work 51, no. 6 (2008): 790-812.

100 Gert J. J. Biesta, Learning Democracy in School and Society: Education, Lifelong Learning, and the Politics of Citizenship (Rotterdam: Sense Publishers, 2011).

101 Hobor," Surviving the Era of Deindustrialization," 417. 
to amount to what has once been coined a "community revolution."102 What is needed for that are "social imagineers" instead of "social engineers."103 As Lawrence Cremin wrote, referring to the motto on the Great Seal of the United States: 'Democracy becomes the persistent quest for the 'more perfect union,' a kind of continuing social process of e pluribus unum [out of many, one]."104 This quest makes it worth to connect past, present, and future and to look beyond the "age of steel."

\section{Sources and Bibliography}

Alder, Simeon, David Lagakos, and Lee Ohanian. Competitive Pressure and the Decline of the Rust Belt: A Macroeconomic Analysis. NBER Working Paper No. 20538. Cambridge, MA: National Bureau of Economic Research, 2014.

Apel, Dora. Beautiful Terrible Ruins: Detroit and the Anxiety of Decline. New Brunswick, NJ: Rutgers University Press, 2015.

Bell, Daniel, and Virginia Held. “The Community Revolution.” The Public Interest 16 (1969): 142-77.

Betten, Neil, and Raymond A. Mohl. "The Evolution of Racism in an Industrial City, 1906-1940: A Case Study of Gary, Indiana." The Journal of Negro History 59, no. 1 (1974): 51-64.

Biesta, Gert J. J. Learning Democracy in School and Society: Education, Lifelong Learning, and the Politics of Citizenship. Rotterdam: Sense Publishers, 2011.

Bliss, Don C. "Platoon Schools in Practice." The Elementary School Journal 20, no. 7 (1920): 510-15.

Bloomberg, Warner, Jr., and Victor F. Hoffmann, Jr. “The Recession Hits Gary, Indiana: Smiling Through?" Commentary 26, no. 1 (1958):15-21.

Bobbitt, John Franklin. “The Elimination of Waste in Education.” The Elementary School Teacher 12, no. 6 (1912): 259-71.

Bourne, Randolph S. The Gary Schools. Cambridge, MA: MIT Press, 1970. First published 1916 by Houghton Mifflin Co. (Boston).

Brickman, William W. Introduction to Schools of Tomorrow, by John Dewey and Evelyn

Dewey, ix-xxvi. 1915. Reprint, New York: E. P. Dutton \& Co., 1962.

102 Daniel Bell and Virginia Held, "The Community Revolution," The Public Interest 16 (1969): 142-77; Hurley, "Challenging Corporate Polluters," 299.

103 Henry A. Giroux, The Mouse that Roared: Disney and the End of Innocence (Lanham, MD: Rowman and Littlefield, 1999); Leonardo and Hunter, "Imagining the Urban," 779.

104 Cremin, The Transformation of the School, 121; see also Robert D. Putnam, "E Pluribus Unum: Diversity and Community in the Twenty-First Century. The 2006 Johan Skytte Prize Lecture," Scandinavian Political Studies 30, no. 2 (2007): 137-74. 
Brook, Anthony. “Gary, Indiana: Steeltown Extraordinary." Journal of American Studies 9, no. 1 (1975): 35-53.

Buder, Stanley. Pullman: An Experiment in Industrial Order and Community Planning, 1880-1930. New York: Oxford University Press, 1967.

Callahan, Raymond E. Education and the Cult of Efficiency: A Study of the Social Forces that Have Shaped the Administration of the Public Schools. Chicago: University of Chicago Press, 1970.

Cohen, Ronald D. Children of the Mill: Schooling and Society in Gary, Indiana, 19o6-196o. Bloomington: Indiana University Press, 1990.

Cremin, Lawrence A. The Transformation of the School: Progressivism in American Education 1876-1957. New York: Vintage Books, 1961.

Cuban, Larry. "How Schools Change Reforms: Redefining Reform, Success and Failure." Teachers College Record 99, no. 3 (1998): 453-77.

De Coster, Tom, Marc Depaepe, Frank Simon, and Angelo Van Gorp. "Dewey in Belgium: A Libation for Modernity? Coping with His Presence and Possible Influence." In Inventing the Modern Self and John Dewey: Modernities and the Travelling of Pragmatism in Education, edited by Tom Popkewitz, 85-109. New York: Palgrave Macmillan, 2005 .

[Decroly, Ovide.] Dr. Ovide Decroly, 1871-1932: Toespraakgehouden te Ronse in 1904: Tekst van de onuitgegeven redevoering. Ghent: Departement Onderwijs, [1904].

Decroly, Ovide. "Discours d'ouverture: Ve Congrès belge de Neurologie et de Psychiatrie (Mons, 25-26 septembre 1909)." Journal de Neurologie 14, no. 21 (1909): 408-15.

Decroly, Ovide. "Plaies sociales et remèdes." Revue Contemporaine: Pour l'École 1 (1904): 406-10.

Decroly, Ovide. "Prophylaxie et traitement de l'enfance anormale: Le rôle du médecin." L'École Nationale 9, no. 2 (1909): 4-5.

Decroly, Ovide. "Questionnaire pour servir à la confection du dossier médico-pédagogique." La Policlinique 15, no. 15 (1906): 225-34.

Decroly, Ovide, and Raymond Buyse. Les applications américaines de la psychologie à l'organisation humaine et à l'éducation. Brussels: Lamertin, 1923.

Decroly, Ovide, et al. "Questionnaire pour servir à la confection du dossier médicopédagogique." La Policlinique 15, no. 15 (1906): 225-34.

De Genova, Nicholas. "The Stakes of an Anthropology of the United States." The New Centennial Review 7, no. 2 (2007): 231-77.

Depaepe, Marc. Between Educationalization and Appropriation: Selected Writings on the History of Modern Educational Systems. Leuven: Leuven University Press, 2012.

Depaepe, Marc, and Lieven D'hulst, eds. An Educational Pilgrimage to the United States: Travel Diary of Raymond Buyse, 1922. Leuven: Leuven University Press, 2011.

Dewey, John. Democracy and Education: An Introduction to the Philosophy of Education. New York: Macmillan, 1916. 
Dewey, John. The School and Society: Being Three Lectures. Chicago: University of Chicago Press, 1899.

Dewey, John. "The School as a Means of Developing a Social Consciousness and Social Ideals in Children." National Conference on Social Welfare Proceedings (1923): 449-53.

Dewey, John, and Evelyn Dewey. Schools of Tomorrow. 1915, Reprint, New York: E. P. Dutton, 1962.

Eilers, Kerstin. "René Sand (1877-1953) and His Contribution to International Social Work, IASSW-President 1946-1953." Social Work \& Society 5, no. 1 (2007): 102-9.

Fallace, Thomas D. Race and the Origins of Progressive Education, 1880-1929. New York: Teachers College Press, 2015.

Fallace, Thomas D. "Recapitulation Theory and the New Education: Race, Culture, Imperialism, and Pedagogy, 1894-1916." Curriculum Inquiry 42, no. 4 (2012): 510-33.

Fallace, Thomas D. "Repeating the Race Experience: John Dewey and the History Curriculum at the University of Chicago Laboratory School." Curriculum Inquiry 39, no. 3 (2009): $381-405$.

Fallace, Thomas D. "Was John Dewey Ethnocentric? Reevaluating the Philosopher's Early Views on Culture and Race." Educational Researcher 39, no. 6 (2010): 471-77.

Gard, Michael, and Carolyn Pluim. Schools and Public Health: Past, Present, Future. Lanham, MD: Lexington Books, 2014.

Giroux, Henry A. The Mouse that Roared: Disney and the End of Innocence. Lanham, MD: Rowman and Littlefield, 1999.

Grandin, Greg. “Empire's Ruins: Detroit to the Amazon.” In Imperial Debris: On Ruins and Ruination, edited by Anna Laura Stoler, 115-28. Durham, NC: Duke University Press, 2013.

Healy, Lynne M. "Introduction: A Brief Journey Through the 8o Year History of the International Association of Schools of Social Work." Social Work \& Society 6, no. 1 (2008): $115^{-27 .}$

Herman, Frederik, Angelo Van Gorp, Frank Simon, and Marc Depaepe. "Auf den Spuren von Diskurs, Traum und Wirklichkeit der architektonischen Formgebung in Decrolys Ermitage." Zeitschrift für Pädagogik 57 (2011): 928-51.

Herman, Frederik, Angelo Van Gorp, Frank Simon, and Marc Depaepe. "Modern Architecture Meets New Education: Renaat Braem's Design and the Brussels Decroly School (1946)." Belgisch Tijdschrift voor Nieuwste Geschiedenis/Revue Belge d'Histoire Contemporaine 41, nos. 1-2 (2011): 135-66.

Hobor, George. "Surviving the Era of Deindustrialization: The New Economic Geography of the Urban Rust Belt." Journal of Urban Affairs 35, no. 4 (2012): 417-34.

Hurley, Andrew. "Challenging Corporate Polluters: Race, Class and Environmental Politics in Gary, Indiana, since 1945." Indiana Magazine of History 88 (1992): 273-302. 
Johnson, Mordecai W. "The Negro and His Relationships." National Conference on Social Welfare Proceedings (1937): 56-70.

Kliebard, Herbert M. The Struggle for the American Curriculum 1893-1958. 3rd ed. New York: RoutledgeFalmer, 2004.

Kniephoff-Knebel, Anette, and Friedrich W. Seibel. "Establishing International Cooperation in Social Work Education: The First Decade of the International Committee of Schools for Social Work (ICSSW)." International Social Work 51, no. 6 (2008): 790-812.

Leonardo, Zeus, and Margaret Hunter. "Imagining the Urban: The Politics of Race, Class, and Schooling." In International Handbook of Urban Education, edited by William T. Pink and George W. Noblit, 779-801. Dordrecht: Springer, 2007.

Levine, Adeline, and Murray Levine. "Introduction to the New Edition: The Gary Schools, A Sociohistorical Study of the Process of Change." In Bourne, The Gary Schools, xii-lv.

Levine, David. "The Milwaukee Platoon School Battle: Lessons for Activist Teachers." The Urban Review 34, no. 1 (2002): 47-69.

Lytle, James H. “Urban School Reform: To What End?” In International Handbook of Urban Education, edited by William T. Pink and George W. Noblit, 859-81. Dordrecht: Springer, 2007.

Margonis, Frank. "John Dewey's Racialized Visions of the Student and Classroom Community." Educational Theory 59 (2009): 17-39.

McCormick, Virginia E. Architecture in Ohio: From One-Room Schools and Carnegie Libraries to Community Education Villages. Kent, OH: Kent State University Press, 2001.

McShane, Stephen G., and Gary S. Wilk. Steel Giants. Bloomington, IN: Quarry Books, 2009 .

Naparstek, Arthur J. "Community Empowerment: The Critical Role of Neighborhoods.” National Conference on Social Welfare Proceedings (1980): 53-64.

Nye, Robert A. "The Evolution of the Concept of Medicalization in the Late Twentieth Century." Journal of the History of the Behavioral Sciences 39, no. 2 (2003):115-29.

Ohanian, Lee E. Competition and the Decline of the Rust Belt. Economic Policy Paper 14-6, Federal Reserve Bank of Minneapolis. https://www.minneapolisfed.org/ / media/files/pubs/eppapers/14-6/epp_14-6_rev.pdf.

O'Hara, S. Paul. Gary: The Most American of All American Cities. Bloomington: Indiana University Press, 2011.

Peters, Michael A. "Why Is My Curriculum White?" Educational Philosophy and Theory 47, no. 7 (2015): 641-46.

Priem, Karin, and Frederik Herman. "'Sensuous Geographies' in the 'Age of Steel': Educating Future Workers' Bodies in Time and Space (1900-1940)." In this volume. 
Putnam, Robert D. "E Pluribus Unum: Diversity and Community in the Twenty-First Century. The 2006 Johan Skytte Prize Lecture." Scandinavian Political Studies 30, no. 2 (2007): 137-74.

Rabinbach, Anson. The Human Motor: Energy, Fatigue, and the Origins of Modernity. Berkeley: University of California Press, 1992.

Reese, William J. Foreword to Children of the Mill: Schooling and Society in Gary, Indiana, 1906-196o, by Ronald D. Cohen, ix-xii. Bloomington: Indiana University Press, 1990.

"René Sand [obituary]," American Journal of Public Health 43 (1953): 1476-77.

Richardson, Theresa. "Moral Imperatives for the Millennium: The Historical Construction of Race and Its Implications for Childhood and Schooling in the Twentieth Century." Studies in Philosophy and Education 19 (2000): 301-27.

Sand, René. Advance to Social Medicine. Translated by Rita Bradshaw. New York: Staples Press, $195^{2}$.

Sand, René. La Belgique sociale [Un inventaire et un plan d'action]. Brussels: J. Lebègue, 1933.

Sand, René. La santé de l'écolier. Brussels: Maison nationale d'édition l'Églantine, 1923.

Sand, René. L'économie humaine par la médecine sociale. Paris: Les Éditions Rieder, 1934.

Sand, René. L'économie humaine par la médecine sociale; un programme de la santé pour la Belgique. Brussels: Office de Publicité, 1945.

Sand, René. Organisation industrielle, médecine sociale et éducation civique en Angleterre et aux États-Unis. Brussels: Librairie Maurice Lamertin; Paris: Librairie J.-B. Baillière et fils, 1920.

Sand, René. Vers la médecine sociale. Paris: Baillière et fils, 1948.

Semel, Susan F., and Alan R. Sadovnik, eds. "Schools of Tomorrow, Schools of Today": What Happened to Progressive Education. New York: Peter Lang, 1999.

Shaw, Ian. "Social Work Research: An Urban Desert?" European Journal of Social Work 14, no. 1 (2011): 11-26.

Smeyers, Paul, and Marc Depaepe, eds. Educational Research: The Educationalization of Social Problems. Dordrecht: Springer, 2009.

Stoler, Ann Laura. "Imperial Debris: Reflections on Ruins and Ruination." Cultural Anthropology 23, no. 2 (2008): 191-219.

Sugrue, Thomas J. The Origins of the Urban Crisis: Race and Inequality in Postwar Detroit. Princeton, NJ: Princeton University Press, 2005.

Taylor, Graham Romeyn. Satellite Cities: A Study of Industrial Suburbs. New York: Appleton, 1915 .

Tead, Ordway. Instincts in Industry: A Study of Working-Class Psychology. Boston: Houghton Mifflin, 1918. 
Thorburn, Malcolm. "John Dewey, William Wirt and the Gary Schools Plan: A Centennial Reappraisal." Journal of Educational Administration and History 49, no. 2 (2017): 144-56.

Turmel, André. “Towards a Historical Sociology of Developmental Thinking: The Case of Generation." Paedagogica Historica 40, no. 4 (2004): 419-33.

Van Gorp, Angelo. "From Special to New Education: The Biological, Psychological, and Sociological Foundations of Ovide Decroly's Educational Work (1871-1932)." History of Education 34, no. 2 (2005): 135-49.

Van Gorp, Angelo. “Ovide Decroly: Warum sollten wir ihn erforschen?” Zeitschrift für pädagogische Historiographie 13, no. 1 (2007): 6-13.

Van Gorp, Angelo. Tussen mythe en wetenschap: Ovide Decroly (1871-1932). Leuven: Acco, 2005.

Van Gorp, Angelo, Marc Depaepe, and Frank Simon. "Backing the Actor as Agent in Discipline Formation: An Example of the 'Secondary Disciplinarization' of the Educational Sciences, Based on the Networks of Ovide Decroly (1901-1931)." Paedagogica Historica 40, nos. 5-6 (2004): 591-616.

Wirt, William Albert. Newer Ideals in Education: The Complete Use of the School Plant. An Address Delivered Before the Public Education Association in the New Century Drawing Room, January 3o, 1912. Philadelphia: Public Education Association, 1912.

Zilversmit, Arthur. Changing Schools: Progressive Education Theory and Practice, 1930196o. Chicago: University of Chicago Press, 1993. 